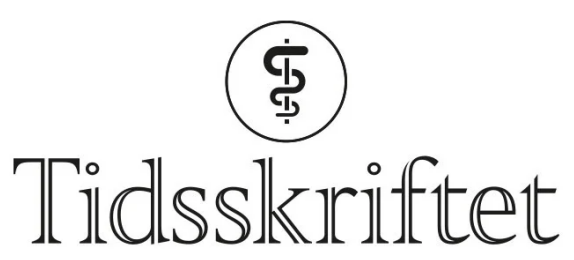

DEN NORSKE LEGEFORENING

\title{
Gunnar Haukenes
}

MINNEORD

LARS HAARR

BIRGITTA ÅSJÖ

KARL-HENNING KALLAND

ELLING ULVESTAD

HELGE MYRMEL

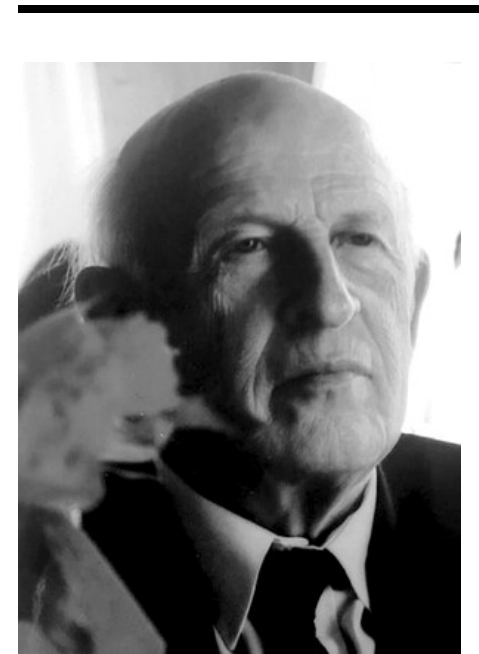

Ein nestor i norsk virologi, tidlegare professor og overlege Gunnar Haukenes er gått bort. Han var ein sympatisk og dyktig forelesar og forskar med stor kunnskap som kom mange til nytte.

Haukenes døde 21. august 2021 etter eit kort sjukeleie. Han var fødd i Arendal i 1927 og var gåverik intellektuelt og musikalsk. Valet stod mellom pianistkarriere eller legeutdanning. Det vart medisinsk embetseksamen i Oslo i 1951.

Han vart assistentlege ved Bakteriologisk avdeling (bakteriologi og serologi) ved Gades institutt i Bergen i 1956. Haukenes starta mikrobiologisk forsking i Allégaten 49, som var viktig for oppbygginga av mikrobiologiske og immunologiske fagfelt i Bergen. 
I 1962 forsvarte han doktorgraden Immunochemical studies on Polysaccharide A from Staphylococcus aureus og følgde opp med vidare bakteriologiarbeid.

Haukenes sin faglege identitet er imidlertid knytt til oppbygging av virologisk forsking og diagnostikk i Bergen, med studiar av influensavirus, rubellavirus, meslingvirus og hiv.

I 1966 vart Viruslaboratoriet oppretta i dagens Armauer Hansens hus, leia av Haukenes som dosent ved Avdeling for mikrobiologi og immunologi og overlege i virologi ved Haukeland sjukehus. Her bygde Haukenes opp virologisk forsking og diagnostikk i Bergen, frå 1972 med professorat i virologi.

Med aidsepidemien vart virologien eit topprioritert forskingsfelt. Forskingsrådet vedtok, som si største enkeltsatsing til då, å opprette eit nasjonalt senter for virologisk forsking i 1988. Haukenes vart første leiar, med ei rekke virologiske bidrag av internasjonalt format frå miljøet.

Utover 1990-åra gjennomgjekk virusdiagnostikken ein revolusjon, med påvising av arvestoff frå virus som alternativ til serologi. Haukenes la framsynt til rette for dette. Han leia vidare- og etterutdanningskurs for legar, kalla «Nytt om virus - og nye virus», var redaktør for APMIS og forfatta lærebøker.

Kunnskapsregisteret i medisinsk mikrobiologi var kolossalt og han vart omtala som ein av Skandinavias fremste virologar i si tid. Dei som banka på kontordøra hans, møtte alltid ein sympatisk mann med stor integritet, og dei kunne som oftast forlate kontoret med nye innsikter.

Ein kjær hobby var tennis saman med kona Ruth, som har vunne fleire noregsmeisterskap, og med døtrene Ellen, Inger og Anne. Dei siste åra bodde Haukenes ved Fantoft omsorgssenter, der han dagleg spelte piano - til glede for beboarane og tilsette. Fred og ære over minnet.

For kollegaer ved Universitetet $i$ Bergen og Haukeland universitetssjukehus.

Publisert: 11. oktober 2021. Tidsskr Nor Legeforen. DOI: 10.4045/tidsskr.21.0646

(C) Tidsskrift for Den norske legeforening 2023. Lastet ned fra tidsskriftet.no 26. april 2023. 